\title{
A Field Measurement of Noise Comfort Classroom in Xaverius Pringsewu Senior High School
}

Christina $^{1}$, Ai Siti Munawaroh ${ }^{2}$

Christina.17331015@student.ubl.ac.id ${ }^{1}$, aisiti.arch@ubl.ac.id ${ }^{2}$

Department of Architecture, Faculty of Engineering, Universitas Bandar Lampung ${ }^{1}$, Universitas Bandar Lampung ${ }^{2}$

\section{Abstrak}

Sekolah adalah tempat semua kegiatan belajar dilakukan oleh siswa. Kegiatan pembelajaran di dalam kelas harus memenuhi standar kenyamanan yang baik terutama faktor kebisingan. Kebisingan kelas dapat disebabkan oleh faktor eksternal dan internal. Tingkat kenyamanan pendengaran untuk ruang kelas adalah standar 55 DBA. Tujuan dari penelitian ini adalah untuk mengetahui dan menganalisis tingkat kenyamanan kebisingan pada ruang kelas di SMA Xaverius Pringsewu. Metode penelitian yang digunakan adalah pengukuran lapangan menggunakan sound level meter. Selain itu dilakukan survey terhadap pengguna gedung dengan kuesioner untuk mengetahui persepsi kenyamanan audio. Ruang kelas yang diteliti memiliki desain ruang kelas dimana ventilasi dinding kedua kelas memiliki ketinggian yang berbeda. Dengan desain ventilasi yang berbeda tentunya akan mempengaruhi kondisi kebisingan di dalam kelas. Hasil penelitian menunjukkan bahwa sumber bising berasal dari lapangan basket, speaker masjid, dan jalan raya. Ruang kelas RK 1 lebih bising dibandingkan ruang kelas RK 2 karena perbedaan desain kelas dimana ruang kelas RK 1 memiliki ventilasi yang lebar pada dinding, sedangkan ruang kelas RK 2 memiliki ruangan tertutup dengan ventilasi pada pintu dan jendela.

Kata Kunci : tingkat kenyamanan kebisingan, dampak kebisingan, faktor-faktor kebisingan, vegetasi, ruang kelas

\section{Abstract}

A school is a place where all learning activities are carried out by students. Learning activities in the classroom must meet good standards of comfort, especially the noise factor. Class noise can be caused by external and internal factors. The hearing comfort level for classrooms is the standard 55 DBA. The purpose of this study was to determine and analyze the comfort level of noise in a classroom at SMA Xaverius Pringsewu. The research method used is field measurements using a sound level meter. In addition, a survey was conducted on building users using a questionnaire to determine the perception of audio comfort. The researched classroom has a classroom design where the ventilation walls of the two classes have different heights. A different ventilation design will certainly affect the noise conditions in the classroom. The results showed that the noise source came from the basketball court, mosque speakers, and the highway. The RK 1 classroom is louder than the RK 2 classroom because of the difference in class design where the RK 1 classroom has wide ventilation on the walls. 


\section{Introduction}

Noise is a sound that results from something that produces a sound source level that can interfere with hearing comfort (Khodijah, 2020). Noise can interfere with one's activities, especially in places that require high concentration such as schools. School is a forum for activities that function as a means of learning. In the learning process, it must have a low noise level, where the factors that affect the surrounding sound are not noisy so as not to interfere with the learning process (Singkam, 2020). Schools are also included in places that require quiet conditions and away from the noise. However, for areas that are already included in urban areas, it is very difficult in terms of noise. The object of this school is also included in the city which is still influenced by external factors, namely the problem of traffic noise (Hernati, 2018).

The concentration of learning is one aspect of a person's psychology. A person has different levels of concentration. Especially in certain subjects that require high concentration. Of course, the existing noise can interfere with the learning process (Juita, 2020). The higher the student and teacher concentration, the higher the learning effectiveness is carried out. Conversely, if the student's concentration is disturbed, the resulting learning will not be optimal (Halil et al., n.d.).

Concentration is closely related to the center of one's brain in focusing on something. Where a person needs a high center of attention and focuses to absorb a material (Atika, 2020). The resulting high sound level can affect the noise in a room. Affect ongoing learning activities (Print et al., 2018). Classroom comfort must be balanced with the surrounding environment where the factors affect the classroom. When the teacher provides learning material in the classroom and the classroom conditions are noisy, of course, it will also make it difficult for the teacher to deliver the material. Moreover, there is no loudspeaker when delivering the material. This also greatly affects the psychological impact of the teacher(Khodijah, 2020).

Factors that affect the condition of the comfort of the classroom are internal factors and external factors. Internal factors that can affect the noise level, such as the sound from classroom users or electronic noise in the classroom. For external factors that affect the level of traffic noise (Olaosebikan, 2020). The learning process which is influenced by high external factors is the traffic factor. Currently, the development of the city is increasing rapidly which affects traffic vehicles. This also greatly affects the vehicle congestion and air pollution produced. Not only the sound produced from the vehicle makes noise in some areas that require high concentration (Ayu, 2020). The sound generated from vehicle traffic is the volume of the traffic itself at the speed of a vehicle (Nurul Hidayati, 2020).

Traffic noise is a noise level that can reduce and interfere with the concentration of the learning process. Where the noise source generated in the traffic flow comes from vehicles, both twowheeled and four-wheeled vehicles. The resulting traffic activity can also come from the sound 
that comes from the sound of the vehicle's horn and exhaust. The noise level generated by the traffic current produces a noise intensity that reaches 70-80 dBA. While the standard of noise intensity in classrooms is $55 \mathrm{dBA}$ (Khodijah, 2020). Apart from traffic factors, there are several internal factors such as the use of air conditioners from other rooms which disturbs classrooms near the air-conditioned room (Brunner \& Rostiyanti, 2020).

To support a comfortable and effective classroom, a good environment that is far from noise, quiet, and the facilities provided are also adequate. The balance between the environment and classroom conditions will create good effectiveness so that students can produce optimal learning (Lingkungan et al., 2020).

Many things affect the noise from various aspects. For this reason, it is necessary to have audio comfort standards for classrooms so that classrooms can create optimal comfort for students. The noise standard must have an optimal level for a classroom. The level in question is whether the classroom has a low, medium, or high audio level. This issue is relevant as there are many schools with open concept areas where noise levels can reach potentially dangerous levels and can impact student success and teachers' physical health (Singkam, 2020). Class noise can have an impact on students who are in the learning process. The effects are felt such as hearing loss, learning concentration, decreased pronunciation (Stamatis \& Ntouka, 2020).

To reduce the noise level, efforts are needed to handle it. Handling can be done such as planting sufficient vegetation around the classroom, the presence of barriers in the classroom, or making soundproofing in the classroom. This of course will greatly affect the reduction of noise levels (Zikri et al., 2012).

The purpose of this study was to determine and analyze the comfort level of noise in the classroom at Xaverius Pringsewu High School. This school has a classroom design with a wide-open ventilation space. Then a comparison will be made between classes that have wide classroom ventilation with closed classrooms. Of course, this will affect the level of sound produced in the two classrooms.

\section{Method}

The research method used in this study is to take direct measurements in the classroom and send questionnaires to Xaverius Pringsewu high school students and students. The measurements were carried out for five days, Monday-Friday. Meanwhile, the measurement time was carried out for eight hours. For the measurement of noise levels, this is carried out for two areas, namely the indoor area and the outdoor area. The results of the noise level for the two classes were taken as the highest average in each day and hour. 
Figure 1: Sound Level Meter

Source: http://alatproyek.com/digital-sound-level-meter-sanfix-gm1356.html

Table 1: Important dates of Sound Level Meters

\begin{tabular}{|c|c|}
\hline Tools & Specification \\
\hline \multirow{6}{*}{$\begin{array}{l}\text { Sound Level } \\
\text { Meter }\end{array}$} & $\begin{array}{l}\text { - Digital Sound Level : } \\
\text { GM1356 }\end{array}$ \\
\hline & $\begin{array}{l}\text { - Measuring Range : } 30 \text { - } \\
130 \mathrm{dBA}, 35-130 \mathrm{dBC}\end{array}$ \\
\hline & - Accuracy : $1.5 \mathrm{~dB}$ \\
\hline & $\begin{array}{l}\text { Digit \&Resolution : } 5 \\
\text { digit \& } 0.1 \mathrm{~dB}\end{array}$ \\
\hline & $\begin{array}{l}\text { - Frequency Response: } \\
31.5 \mathrm{~Hz} 8.5 \mathrm{KHz}\end{array}$ \\
\hline & $\begin{array}{l}\text { Measuring Level : 30- } \\
\text { 130, 40-90, 50-100, 60- } \\
\text { 110, 80-130 }\end{array}$ \\
\hline
\end{tabular}

SKU:GM-1356

Source:http://alatproyek.com/digital-sound-level-meter-sanfix-gm1356.html

\section{Result and Discussion}
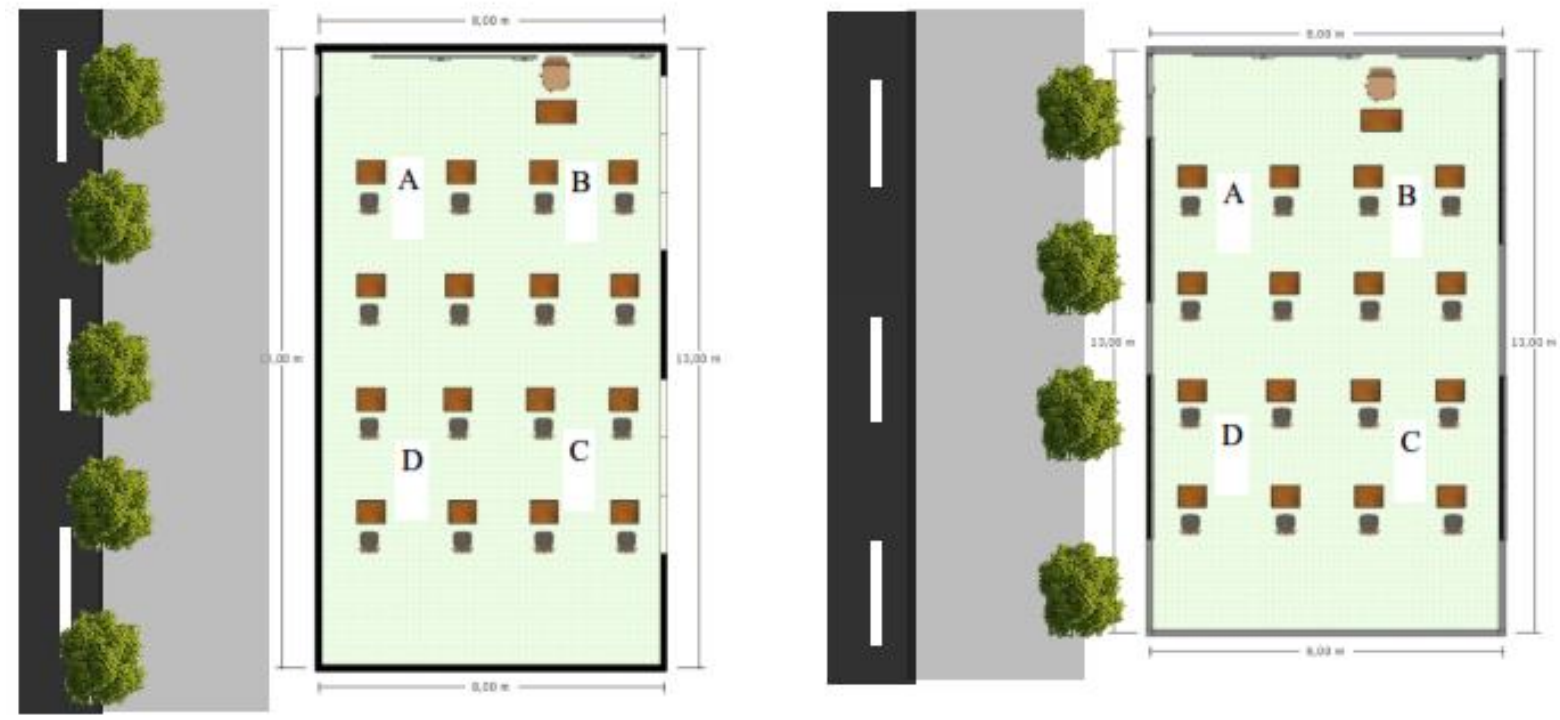

Figure 2: Classroom RK 1 and RK 2

Figure 2 is th econdition of the RK 1 and RK 2 classrooms where there are 16 student desks and chairs and 1 teacher's table and chair. In RK 1, whichis in the picture to the left of the condition of the classroom with open ventilation. For RK2 in the image to th eright with the closed ventilation conditions. In this study, the measurement of noise levels was carried out with four points, namely 
point $A$, point $B$, point $C$, and point $D$. The following are pictures of classroom conditions in RK 1 and RK 2:

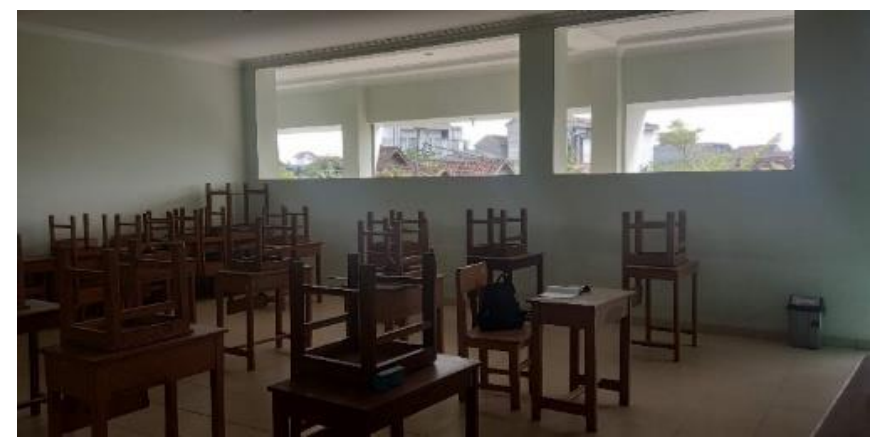

Figure 3: Classroom Indoor RK 1

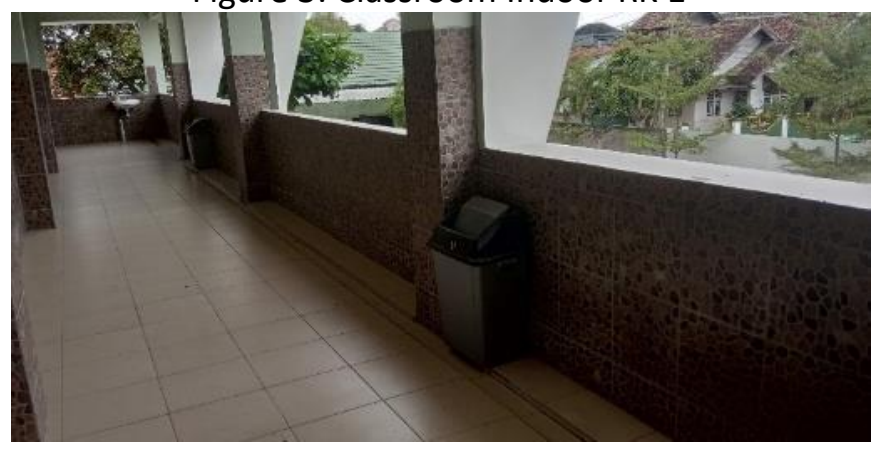

Figure 4: Classroom Outdoor RK 1

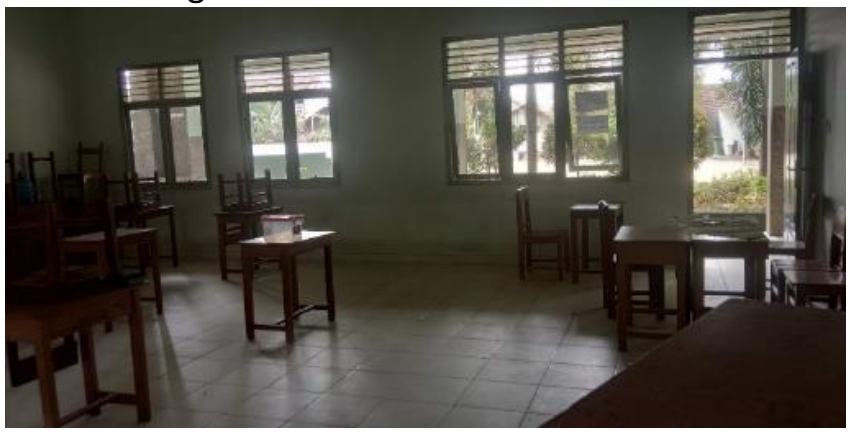

Figure 5: ClassroomIndoor RK 2

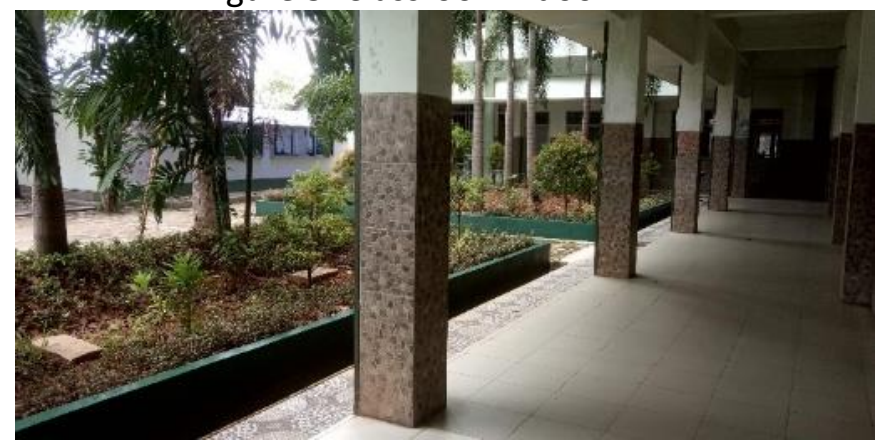

Figure 6: ClassroomOutdoor RK 2

The results of this study were to measure the classroom noise level at Xaverius Pringsewu High School. The measurements were made for two classrooms. The first class is the RK 1 room and the second class is the RK 2 class. The following are the results of measurements of the noise level in the RK 1 room and the RK 2 classroom: 


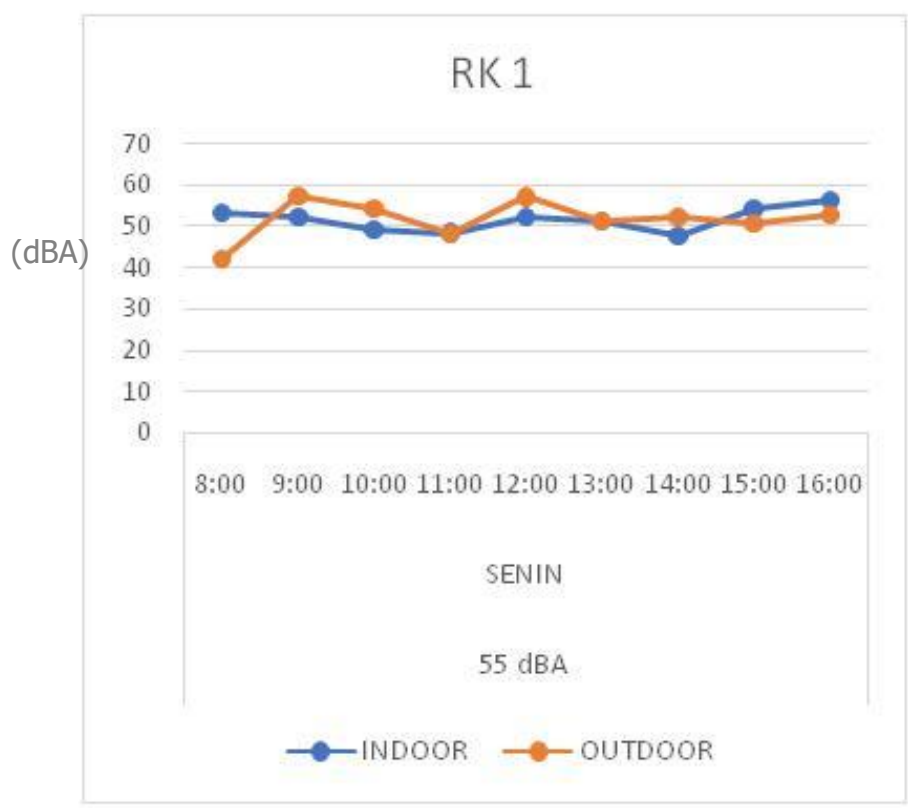

Graphic 1 : Classroom RK 1

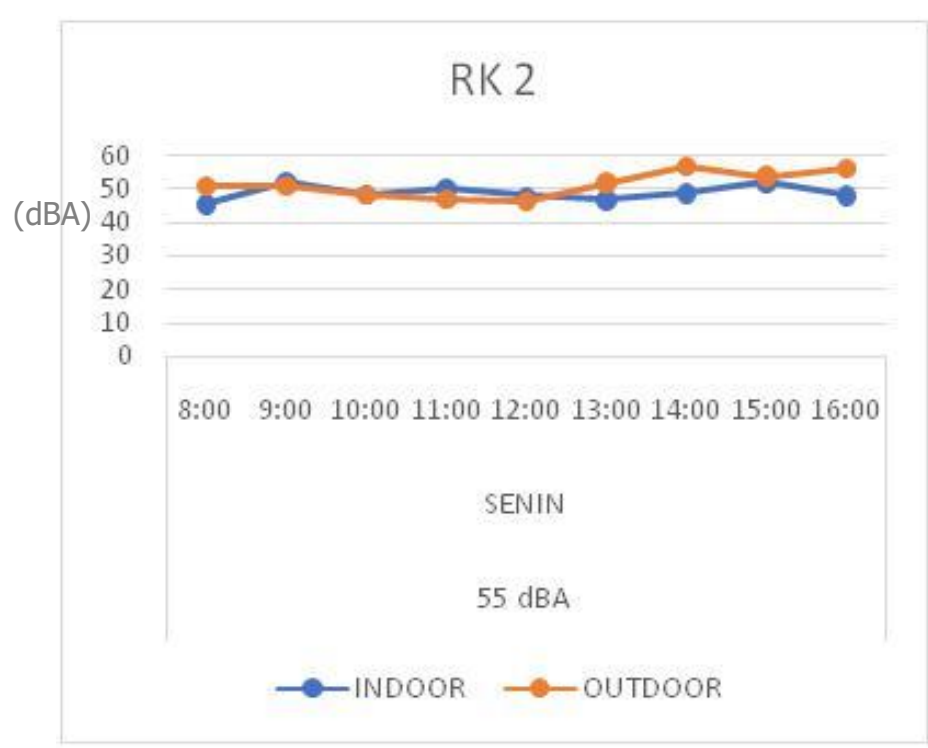

Graphic 2 : Classroom RK 2

The measurement results shown in Graph 1 and Graph 2 showed that the average noise intensity on Monday for RK 1 is not too noisy. Wherefrom 08:00 to 16:00 the average obtained is not too high for the indoor area. For the outdoor area, it is also not noisy because on Monday there are no activities that affect it. Then for the RK 2 classroom, the noise intensity is fairly quiet. The average RK 2 classroom on Monday is not much different from the average amount of noise intensity in the RK 1 room. For outdoor areas, it is also not noisy where the average amount is still below the noise standard. 


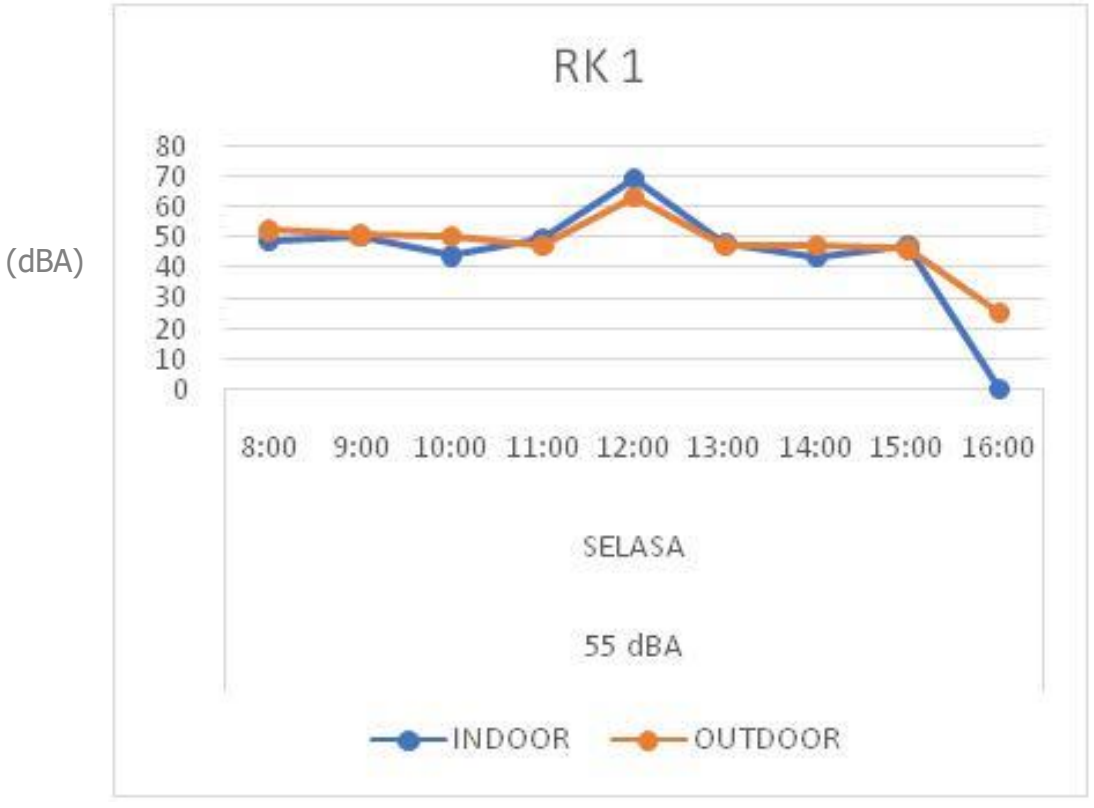

Graphic 3 : Classroom RK 1

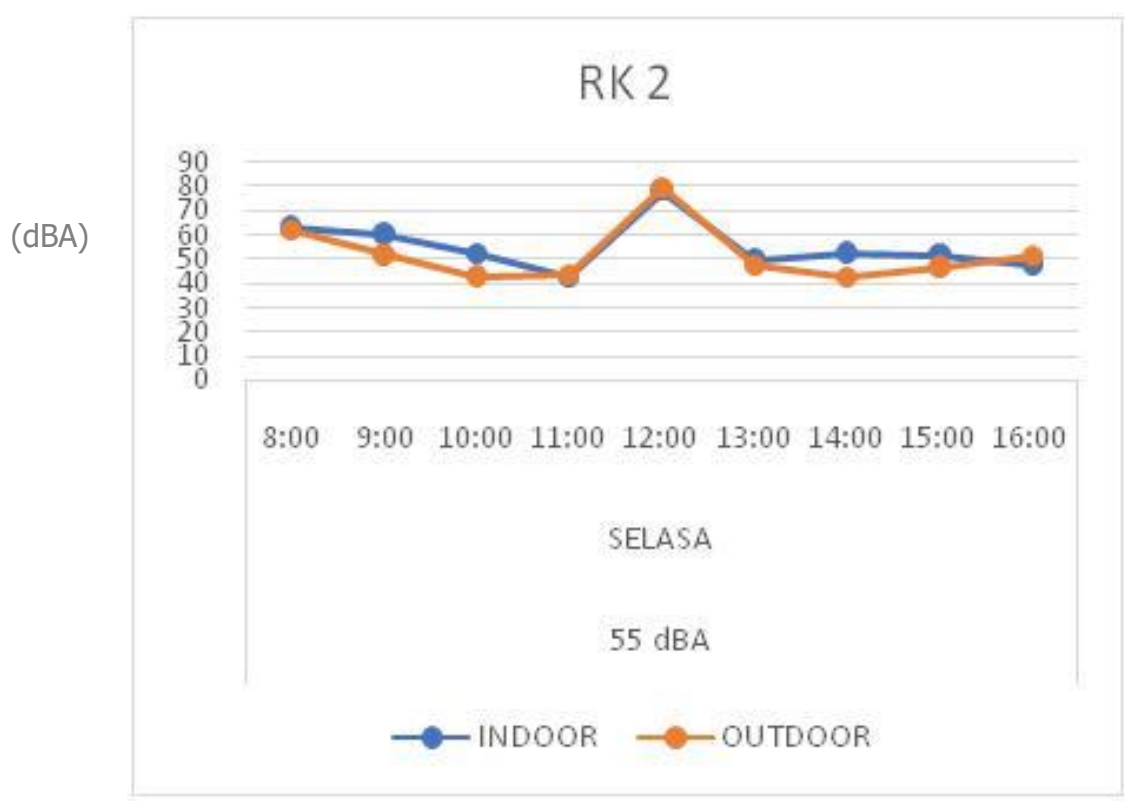

Graphic 4 : Classroom RK 2

On Tuesday, the measurement results showed that the indoor area of RK 1 had the lowest average number at 14:00 with an average of 43.9 DBA and the highest average at 12:00 with the number of 69.7 DBA. Then for the lowest noise intensity for RK 2 is shown at 11:00 and the highest average is at 12:00 with $78 \mathrm{DBA}$. The increased noise intensity for both classrooms was due to the sound of the class speakers for afternoon prayer. For the outdoor area of class XI IPA 2, the lowest average is at 16:00 with 25.3 DBA because the school area is very quiet and for RK 2 it is 42.9 at 11:00. 


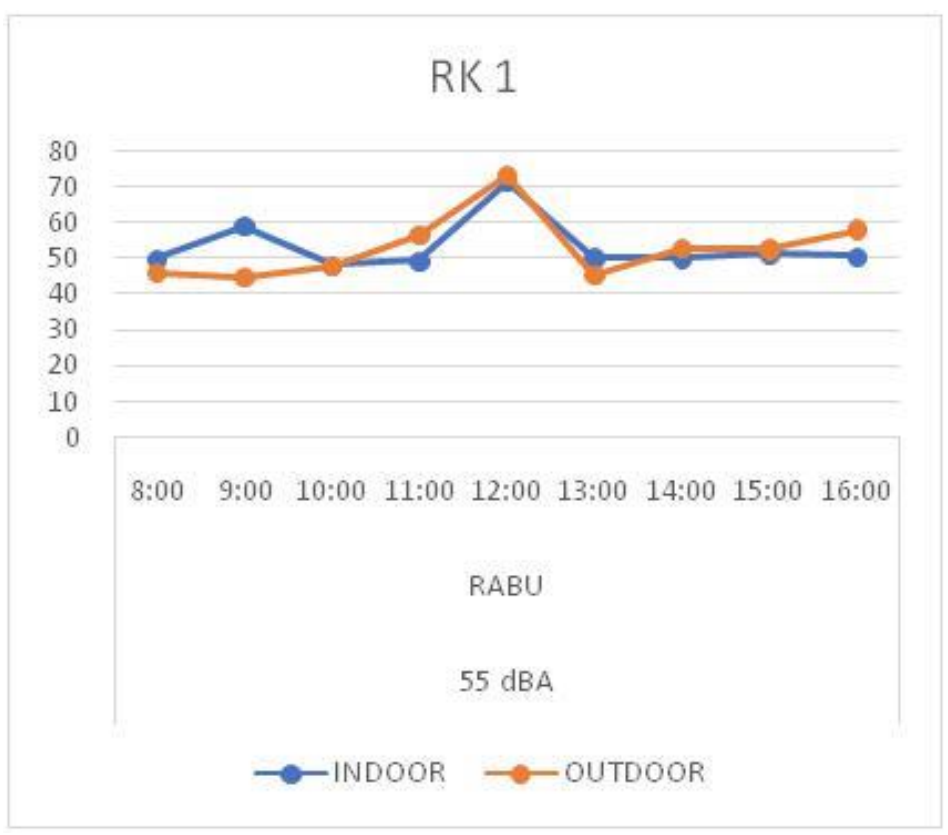

Graphic 5 : Classroom RK 1

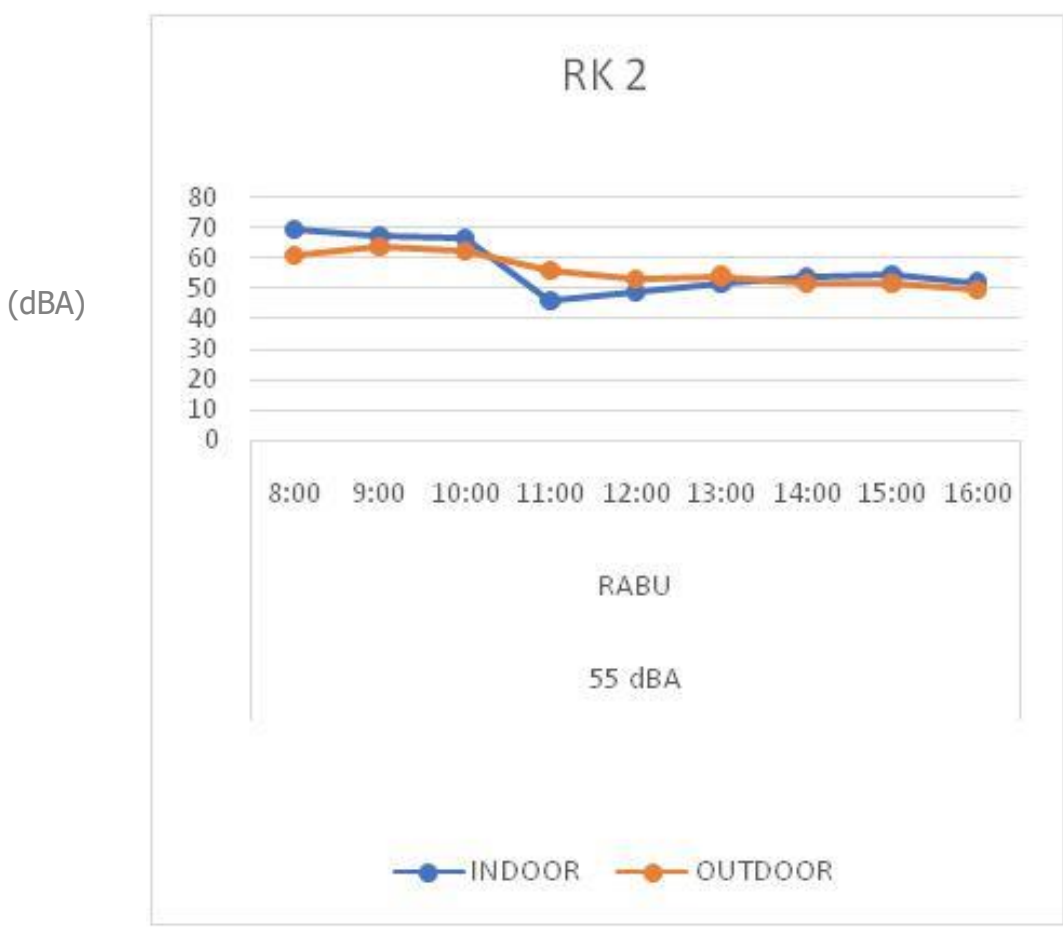

Graphic 6 : Classroom RK 2

In graph 5 and graph 6 on Wednesday the noise intensity for RK 1 is fairly noisy from 08:00 to 12:00 due to traffic factors and classroom speakers and for the following hours, it is fairly quiet. It was still below the standard of noise. For the outdoor area, RK 1 has the lowest noise intensity at 09:00 with 44.6 DBA and the highest average is at 12:00 with 73.45 DBA.

In graph 6 for RK 2 in indoor and outdoor areas, 08:00 to 10:00 is fairly noisy, where the average is above the standard noise due to traffic factors. 


\section{RK 1}

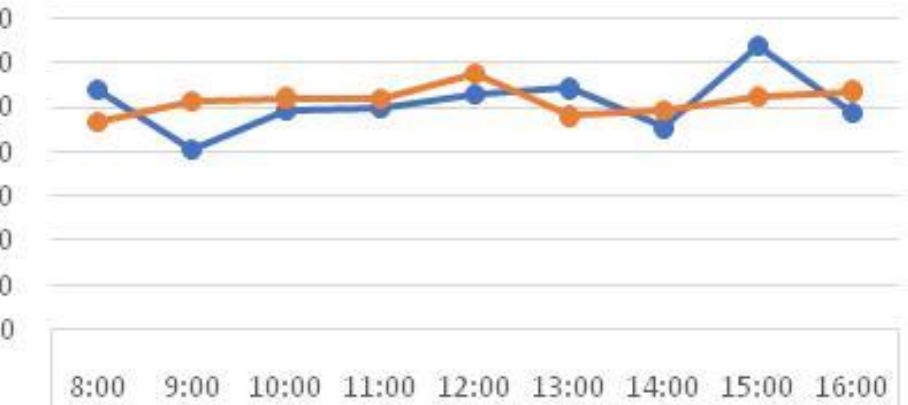

KAMIS

$55 \mathrm{dBA}$

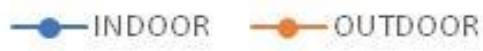

Graphic 7 : Classroom RK 1

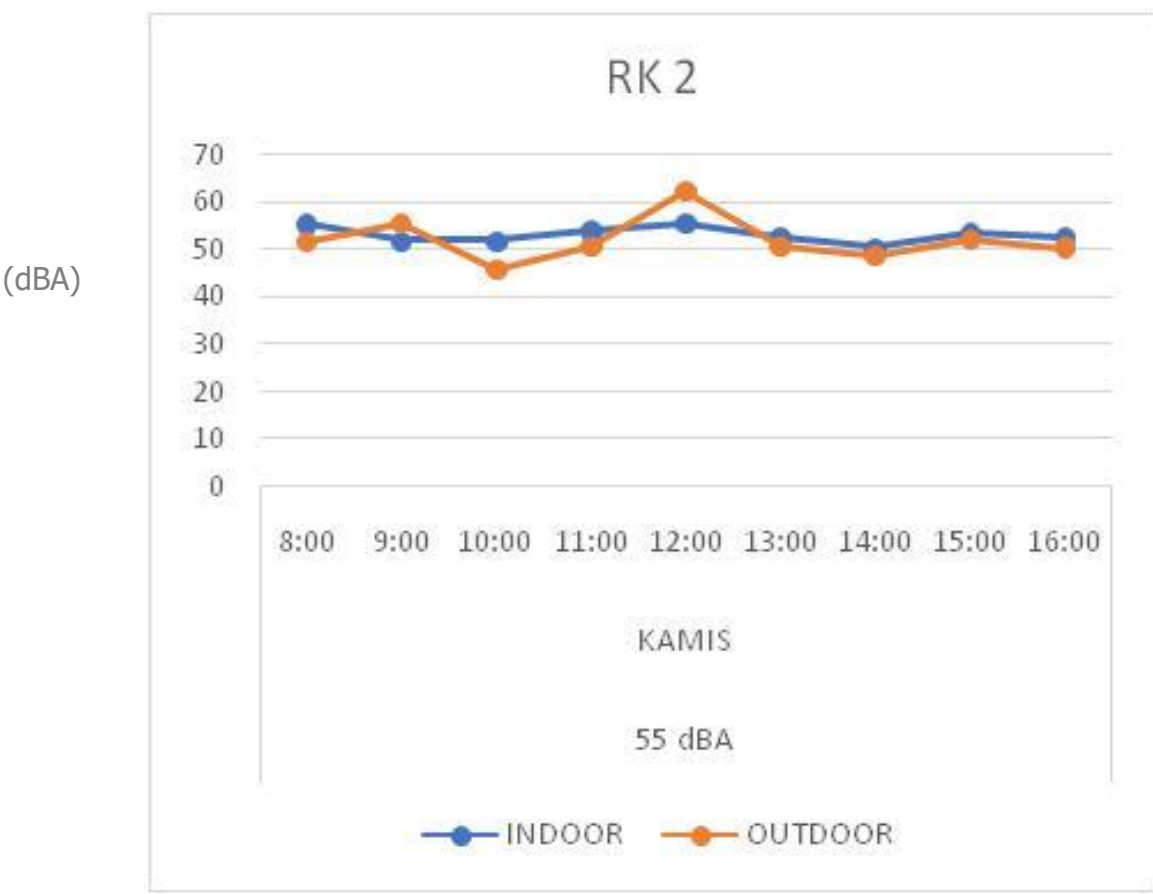

Graphic 8 : Classroom RK 2

On Thursday, which can be seen in graph 7 and graph 8 , it is shown that the highest average for the indoor area is at 15:00 with an average of 64.05 DBA and for the highest average at 09:00 with an average of 40, 7 DBA. Then for the outdoor area, the highest average classroom at 12:00 was 57.65 DBA. Furthermore, for RK 2 the highest average of indoor and outdoor areas was at 12:00 with an average of 55.6 DBA and 62.3 DBA. 


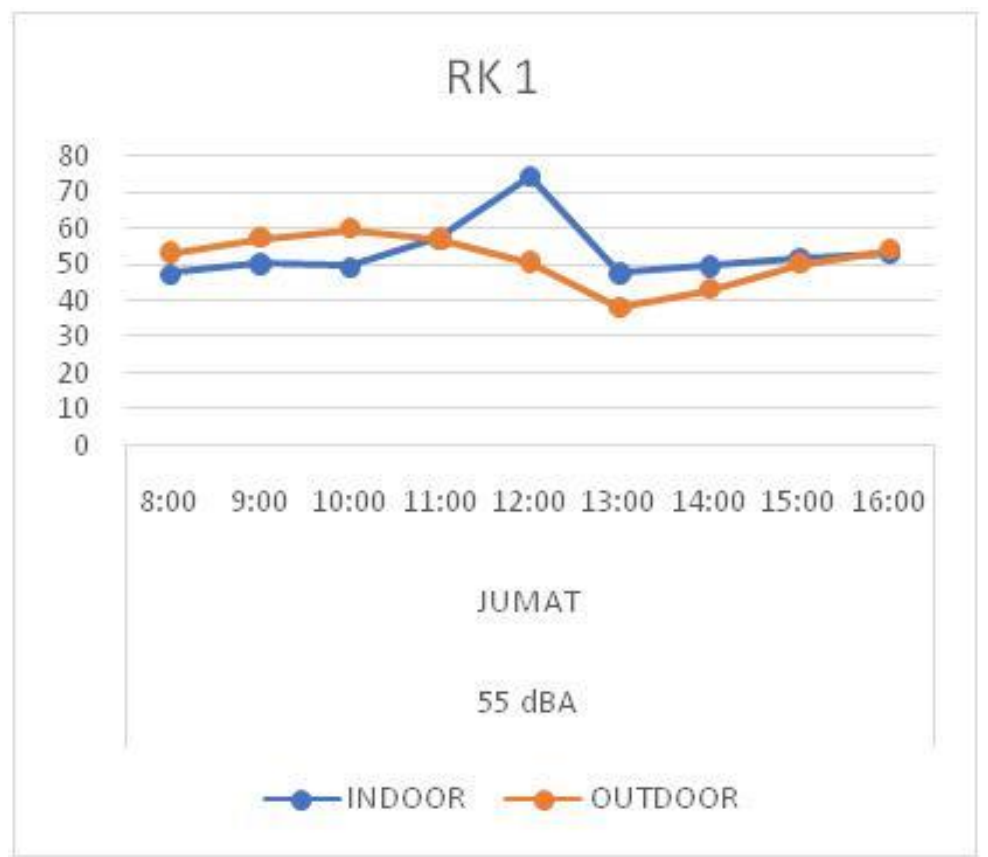

Graphic 9 : Classroom RK 1

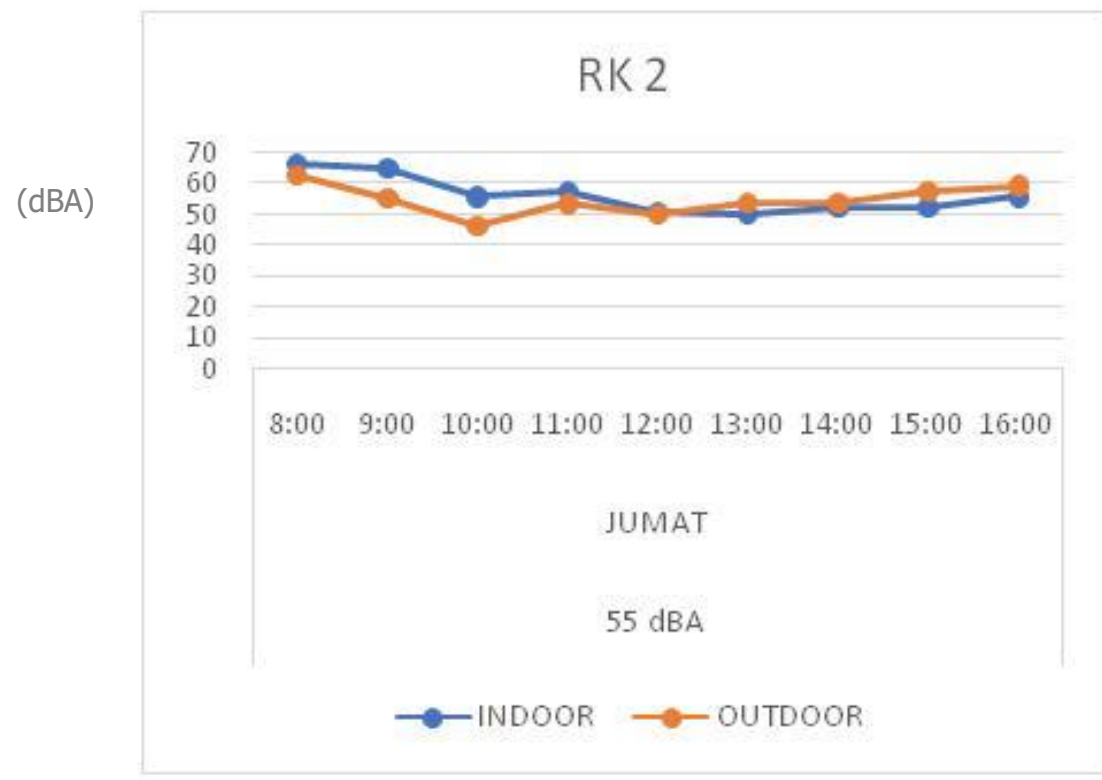

Graphic 10 : Classroom RK 2

On Friday for RK 1 it is shown in graph 9 for the lowest average at 08:00 with 47.6 DBA and for the outdoor area at 15:00 with 50.4 DBA. Then for class X1, the highest average was at 08:00 with an average of 66.6 DBA in the indoor area and the lowest average at 13:00 with 50 DBA. Furthermore, for the outdoor area, the highest average is at 08:00 with 62.4 DBA, and the lowest average at 12:00 with 50.2 DBA. 


\section{Conclusion}

The results obtained from the measurement show that the highest noise intensity is at 12:00 with an average number above the standard of noise, namely on Tuesday it reached $78 \mathrm{dBA}$ for the indoor area, and for the outdoor it reached 79.65 dBA. On Thursday the indoor area reaches 56.5 $\mathrm{dBA}$, the outdoor area reaches $62.3 \mathrm{dBA}$. Then on RK 2 for the indoor area on Tuesday, it reached $69.7 \mathrm{dBA}$, the outdoor area reached $63.3 \mathrm{dBA}$. On Wednesday the indoor area reaches $71.7 \mathrm{dBA}$, the outdoor area is $73.45 \mathrm{dBA}$. On Friday the indoor area reaches $74.5 \mathrm{dBA}$. The average noise exceeds the 55 DBA limit caused by the afternoon prayer class speaker factor. The noise intensity in the two classes was not too noisy because the class was empty due to a pandemic and the learning process was carried out online.

The condition of the classroom RK 1 was noisier than the classroom RK 2 due to the different class design where the classroom RK 1 room had wide classroom ventilation on the wall, while the classroom RK 2 had a closed room with vents on the door and window.

This research has limitations, namely during the COVID-19 pandemic. Therefore, further research is needed under normal conditions and when there are teaching and learning activities in the classroom.

\section{Reference}

Ayu R. D. (2020). Pengaruh kebisingan lalu lintas jalan raya terhadap konsentrasi belajar di sekolah. 1-4.

Bachtiar, V. S., Afrianita, R., \&Zamzamy, A. (2018). Evaluasi Tingkat Kebisingan Kawasan Selatan Universitas Negeri Padang. Junal Dampak, 15, 7-15.

Balirante, M., Lefrandt, \& Kumaat, M. (2020). Analisa Tingkat Kebisingan Lalu Lintas Di Jalan Raya Ditinjau Dari Tingkat Baku Mutu Kebisingan Yang Diiizinkan. 8(2), 249-256.

Halil, A., Yanis, A., \& Noer, M. (2015). Pengaruh Kebisingan Lalulintas terhadap Konsentrasi Belajar Siswa SMP N 1 Padang. Kesehatan Andalas, 4, 53-57.

Hernati. (2018). Pengaruh Kebisingan (Pencemaran Suara) Terhadap Aaktivitas Belajar IPA-Biologi Peserta Didik Kelas VIIISMP-IT Asalam Ambon. Institut Agama Islam Negeri Ambon.

Hidayati, N. (2020). Pengaruh Arus Lalu Lintas Terhadap Kebisingan (Studi kasus beberapa Zona Pendidikan di Surakarta). 7, 45-54.

Indradjaja, I. M., Brunner, M., F., S., \&Rostiyanti. (2020). Kenaikan Tingkat Kebisingan Ruangan Kelas Akibat Pengaruh Penyejuk Udara dan Lalu Lintas. Serambi Engineering, V, 852-860.

Keputusan Menteri Negara Lingkungan Hidup No.48 Tahun 1996

Khodijah, T., Dalimunthe, \& Sari, M. V. R. (2020). Hubungan Kebisingan Dengan Konsentrasi Belajar Siswa di Sekolah Mas Al Washliyah 22 Tembung. Educationand Development, 8, 380-383. 
A Field Measurement of Noise Comfort Classroom in Xaverius Pringsewu Senior High School

Lapp, S. (2018). Noise in Classrooms : ItsImpactonStudentsandHowtoCostEffectivelyManagelt. ActivistScienceand Technology Education, 9, 1-5.

Novrilla, U., \&Zulhaini, A. (2020). Konsentrasi Belajar Peserta Didik di Mas Kabupaten Kuantan Singingi. 1(2), 140-144.

Singkam, A. R. (2020). Kondisi Kebisingan di Gedung Perkuliahan Universitas Bengkulu. ScienceEducation, 4, 14-20.

Syarifuddin, \&Muzir. (2015). Analisis Penentuan Pola Kebisingan Berdasarkan Nilai Ambang Batas. Malikussaleh Industrial Engineering, 4, 36-41.

Wafiroh, A. H. (2013). Pengukuran Tingkat Kebisingan di Lingkungan SMPN 2 Jember. Universitas Jember.

Zikri, M. R., Rahayu, J. D., \&Kadarini, S. N. (2020). Analisis dampak kebisingan terhadap komunikasi dan konsentrasi belajar siswa sekolah pada jalan padat lalu lintas. 1-10. 